\title{
Honra fragmentada: casamento, moralidade e adultério (Belém, 1894-1900)
}

\author{
Ipojucan Dias Campos*
}

\begin{abstract}
RESUMO
O estudo versa sobre os significados da honra masculina no seio de alguns casamentos na cidade de Belém-PA do final do século XIX. Metodológica e teoricamente o texto se concentrou em executar diálogos com o empírico (com as fontes) no sentido de descortinar os significados dados à honra quer pelos maridos, quer pelas esposas e, por esta motivação, as interpretações tiveram essencialmente como matéria-prima a documentação. Isto posto, fizeram-se investimentos diante de condutas classificadas na faculdade de indignas, as quais tiveram o poder de colocar abaixo celebrações nupciais um dia pensadas eternas, porém por motivos variados a envolver princípios da honra (adultérios, sevícias, injúrias, ausência de provisões e de proteção), chegaram ao fim. Em conformidade com isso, as reflexões pautaram-se na lógica de que havia profundas exigências de comportamentos ditos adequados às esposas $e$, diante disso, múltiplas requisições eram cotidianamente colocadas para elas cumprirem, contudo, nestas análises, a honra do marido enquanto grandeza, conquista e colonização da esposa não foi tratada na escala de responsabilidade somente da consorte e sim das personagens que se deram em matrimônio.
\end{abstract}

Palavras-chave: Honra. Moralidade e adultério.

\section{Fragmented honor: marriage, morality and adultery (Belém, 1894-1900)}

\begin{abstract}
The study deals with the meanings of male honor within some marriages in the city of Belém-PA at the end of the 19th century. Methodologically and theoretically, the text focused on dialogues with the empiricist (with the sources) in order to reveal the meanings given to the honor by both husbands and wives, and for this reason, the interpretations essentially had as their raw material the documentation. In this way, investments were made in the conduct of the unworthy faculties, which had the power to place eternal bridal celebrations one day, but for various reasons involving principles of honor (adultery, mistreatment, insults, lack of provisions and protection), have come to an end. Accordingly, the reflections were based on the logic that there were deep demands of appropriate behaviors appropriate to the wives, and, on the face of it, multiple requisitions were daily placed on them to fulfill, however, in these analyzes, the honor of the husband as greatness, conquest and colonization of the wife was not treated on the scale of responsibility only of the consort, but of the characters who gave in marriage.
\end{abstract}

Keywords: Honor. Morality and adultery.

Artigo recebido em 11 jan. 2019.

\footnotetext{
* Doutor em História Social pela Pontifícia Universidade Católica de São Paulo (PUC-SP). Professor Associado I da Faculdade de História da Universidade Federal do Pará (UFPA-IFCH). Docente do Programa de Pós-Graduação em Ciências da Religião da Universidade do Estado do Pará (UEPA). E-mail: ipojucancampos@gmail.com. O presente trabalho foi realizado com apoio da Coordenação de Aperfeiçoamento de Pessoal de Nível Superior - Brasil (CAPES) Código de Financiamento 001.
} 


\section{Introdução}

As análises seguintes localizam-se no final do século XIX na cidade de Belém-PA. O princípio diretor delas é o de compreender, no interior de determinados casamentos, movimentos fragmentadores da honra masculina executados por algumas esposas. Deste ponto inicial, outros provieram: a continuidade da honra do homem casado em nenhuma circunstância dependeu estritamente de condutas ilibadas das consortes, logo, ela se ligava imoderadamente aos bons comportamentos dos maridos como o de garantir provisões $e$ residência $e$ o de defender a companheira e os filhos, então, a instituição sempre foi conjugada através de termos complexos a envolver diversas conjunturas.

Os documentos a sustentar essas interpretações foram algumas ações de divórcio impetradas entre 1894 e 1900, leis republicanas como o Decreto n ${ }^{\circ} 181$ de 24 de janeiro de 1890 que laicizou o casamento e o divórcio e o primeiro Código Penal republicano de 1890, e o jornal "Diário de Notícias" que circulou na cidade do período em pauta. Em torno dos assuntos aqui tratados (casamento, honra e moralidade) a documentação a respeito é bem mais numerosa, todavia, devido às exigências de formatação decidiu-se pelo uso interpretativo somente das citadas acima. Quanto a localização, o primeiro grupo de fontes faz parte do cartório Sarmento e pode ser consultado no Centro de Memória da Amazônia (CMA) da Universidade Federal do Pará (UFPA), na cidade de Belém-PA; já a legislação foi compulsada no Arquivo Público do Estado do Pará e os periódicos repousam na Hemeroteca da Biblioteca Pública do Estado do Pará. Metodologicamente esses documentos foram pensados de forma a localizar as personagens sociais (maridos e esposas, principalmente) nos seus movimentos cotidianos e, para isso, procedeu-se sistemáticos cruzamentos das fontes, ou seja, processos se ligando a legislação e estes estabelecendo elos com os jornais.

Naturalmente, estas reflexões possuem dívidas com alguns pesquisadores pioneiros, dentre os quais Eni de Mesquita Samara (1995, p. 57-71), Luzia Margareth Rago (1993, p. 31-44), Ieda Porchat (1992), Roderick Phillips (1991) e Michelle Perrot (2001, p. 263-285), todavia, na presente interpretação quanto aos campos metodológico e teórico buscou-se analisar a honra por intermédio do empírico, ou seja, esteve-se mais preocupado em se dissecar a documentação a respeito e a partir dela lançar um olhar alternativo do que alinhado a determinada teoria da história.

De posse desses dados iniciais é mister afirmar que honra e moralidade sempre foram desejos tidos enquanto inseparáveis da esposa honrada e também enquanto substantivos aderidos 
ao casamento. Esta premissa se tratava do idealizado, porque entre o possível e o executável havia infinitas variáveis e, por isso, o aspirado nem sempre ocorria na prática. Em conformidade, neste artigo, honra foi interpretada no eixo de sistema de representações, de condutas, de valores e de normas bastante contestado e fragmentado em determinados leitos conjugais; assim sendo, a sua prática não se ligava apenas a único consorte e sim aos companheiros.

A honra intacta ajudava a sustentar o matrimônio. Ela ordenava e irrigava a vida a dois. Ela induzia e consagrava campos de dominação sobre a mulher, entretanto, igualmente, fazia pousar exigências e condições nos ombros dos maridos. No entanto, em torno dessa temática, repita-se, nem sempre os domínios saíram da forma almejada, porquanto, a honra e também a sua fragmentação estruturavam representações no seio do consórcio.

A respeito, seguem algumas notas.

\section{Honra e moralidade}

Os temas honra e moralidade foram assuntos constantes em processos de divórcio impetrados na cidade de Belém no final do século XIX. Em 18 de maio de 1900 Placida de Andrade e Silva com a ajuda do seu advogado Heraclito Pinheiro impetraram auto de divórcio contra Ildefonso João da Silva. As causas a demoverem o desejo de separação foram justificadas através da acusação de sevícias, injúrias e abandono do domicílio conjugal por meio de expulsão violenta; estas condutas, é mister expor, faziam manchar a honra das mulheres casadas. Do exausto convívio sob o mesmo teto surgiram cinco filhos, a saber: Leonor, 14 anos; José, 13; Benjamim, 10; Joaquim, 06 e Marcellino, 01 ano. ${ }^{1}$ Há no libelo, de maneira textual, cuidados a envolver os motivos a sustentar o desenlace e uma prévia defesa da possível incriminação de adultério a ser (futuramente) formulada pelo cônjuge implicado, porquanto autora e advogado desenharam narrativas onde expressavam existir, em meio o casal, indivíduo anônimo autor de cartas, as quais tinham por fim plantar desarmonia no leito doméstico. Infelizmente as missivas não foram anexadas ao processo, no entanto, impetrante e profissional do direito as narraram na dimensão de "pachorramente arranjadas e insistentemente remettidas não só a seo marido como a supplicante". ${ }^{2}$ A partir desses manuscritos ditos sem assinatura, a acusadora expunha em juízo que o réu passou a acusá-la da "grave injúria de ter quebrado a fidelidade conjugal e n`essa convicção começou a infringir-lhe maus tractos, espancando-a de um modo inaudito ao ponto de obrigar a suplicante a retirar-se subtamente de sua companhia". ${ }^{3}$ Efetivamente, havia preocupações relativas ao surgimento de possíveis acusações de deslealdades, por esta razão notase flagrante cautela para se fugir da incriminação da existência de aventuras extra-lar, pois elas expressavam densos insultos à honra. Alain Corbin (2013, p. 439-461) dedicou atenção a este 
respeito, ao historiador a ruptura da honra provocada pela mulher acusava o quanto a incapacidade de dominação no seio conjugal se encontrava deteriorada, desgastada, mas de maneira mais profunda expressava elevado sacrilégio.

O adultério fazia apodrecer camadas a compor o casamento, dentre as quais as da lealdade, cumplicidade e afetividade; por conseguinte, comprimia competentemente ligações familiares nas mais diversas combinações como entre a vizinhança e amigos. A falta de retidão sexual sempre produziu problemas para além do traído(a), traidor(a) e do fornicador(a) externo. O aventureirismo sexual extra jamais esteve totalmente sob o domínio dos adúlteros; se o oposto eles pensavam, havia ao assunto perigosa secundarização do perigo em curso. Os amantes ininterruptamente, "no seu todo", se encontravam vigiados e "todos" sabiam o que se passava. No jogo extraconjugal com seus vigias e sentinelas, nenhum isolamento arquitetônico ou natural colocava-se suficiente à esconderijo aos amantes, estes de alguma forma foram monitorados por "estranhos". Nesta dimensão, a comunidade circulante com olhares preventivos incansáveis, fazia o papel de julgadora. Assim, a maneira com que os próximos eram afetados influenciava a política de opiniões e, por conseguinte, intervenções a serem conduzidas pelos "forasteiros" nos interstícios da vida conjugal. Nestas escalas interpretativas, o Sétimo Mandamento, "Não adulterarás" (Bíblia de Jerusalém, 2002) classifica-se no eixo de um romantismo religioso conservador, o qual - de forma exclusiva - foi incapaz de manter a continência quer a da esposa, quer a do marido.

Juridicamente se precaviam (autora e profissional do direito) de possível atroz denúncia de adultério e, consequentemente, da imputação de ter ofendido a dignidade do esposo. Tudo, estrategicamente, se antecipava para se evitar surpresas desagradáveis, porquanto a acusação de a esposa estabelecer elos extraconjugais conferia ao marido boa dose de indignidade, porque na honra, em muito, se ancorava a dominação masculina, mas quando desrespeitada por aquela que tinha por função solidificá-la através do controle de prazeres externos, a vida do homem tendia a degringolar. A ruptura desta instituição fabricava com rapidez e competência as mais altas fraturas na escala do sofrimento individual-coletivo masculino; o companheiro traído facilmente se alocava na condição de admoestado por seus iguais, por seus próximos, por personagens de todo gênero. Nada restaurava a honra. Nem mesmo o divórcio "atenuava" a conjuntura humilhante de um marido atraiçoado, então, a mulher ao se corromper imputava eterno martírio ao esposo, visto que mesmo depois de separado juridicamente, "não deixava" de ver a sua vida enodoada pelo ato ilegítimo. Outro homem tocar as saliências da uma mulher comprometida, denotava para o marido a perda da autoridade do corpo, a perda da autoconfiança, a perda da segurança, a perda de vínculos de poder diante dela e de si próprio. Divertimentos fora dos elos matrimoniais expressavam degenerescência e falência da vida conjugal. A incontinência demonstrava as falhas da fidelidade e o quanto elas suscitavam teatro de impotência a fornecer manifestações públicas 
de dor e consternação, por assim dizer, muitas vezes, macular a honra dispunha de peso intimidador e paralisante, o que dificultava reações imediatas. Longe de ser simbólica, a honra detinha capitais práticos; ela quando existente se notava, se sentia, se observava; porém, quando o marido detinha a sua posse conseguia se acomodar socialmente de forma confortável diante dos seus iguais.

Concernente as teias a envolver Placida e Ildefonso, esclarecem-se alguns pontos: primeiro, cartas existiram inequivocadamente. Segundo, a própria autora confirmava conter nos manuscritos denúncias de ações adúlteras por ela perpetradas, no entanto, todas seriam mentirosas e arquitetadas engenhosamente por pessoa(s) malévola(s) empenhada(s) estritamente a arruinar a sua honra bem como as das famílias envolvidas: a constituída, a do marido e a sua. Terceiro, mesmo inexistindo acusação de adultério-prostituição por parte do impetrado, preventivamente o grupo autor da ação de divórcio (esposa, testemunhas e advogado) se adiantou em se defender do acachapante atributo, por esta motivação se o mesmo fosse formalizado, aprofundamento o qual curiosamente nunca aconteceu, defesa preliminar já se encontraria em curso. Nas tramas há diversas camadas, contudo, a mais importante - nesta ocasião - é a de compreender que o premente se constituía em se livrar da inculpação de a esposa ser dada à divertimentos extraconjugais e consequentemente de prostituição no leito conjugal, pois esta imputação gozava, quando conveniente, de mesma conotação às ações das meretrizes publicadas nos jornais da época, ${ }^{4}$ ou seja, corruptoras da família.

Embates e preocupações concernentes as mulheres classificadas na condição de prostitutas, variadas vezes figuraram seja nos periódicos, seja nos autos de divórcio. Tal indisciplina se constituía em mal-estar à polícia, à Intendência, ao Governo do Estado e era assunto reputado grave pelos profissionais da imprensa e igualmente tratado ponderosamente pelas testemunhas dos processos de desenlace, famílias dos separandos, advogados, juízes, justiça. Quando o trato ilícito da prostituição feminina, praticava-se no seio do casamento, tudo ficava mais intricado, uma vez que inumeráveis princípios como os da dignidade, os da moral, os dos bons costumes, os da honra, os da sexualidade controlada se encontravam sobejamente questionados. Ao marido, cumpridor ou não das suas obrigações conjugais-familiares, nada se colocava tão devastador como o adultério da esposa, porque a honra, lugar profundamente cultuado e pilastra da sua dignidade, o estranho a tinha invadido. O enodoamento dela, por meio do adultério das consortes, impunha aos esposos diversas inferioridades e inumeráveis angústias e medos, por exemplo, nunca estiveram distantes de suas apreensões os efeitos proporcionados pela derrota a um rival, porque se perdia a posse, direitos e poder de ordem frente a mulher. Nestes tensos jogos, dúvidas colocavam-se no "passado" conjugal, ou seja, passavam a pairar desconfianças sobre a cabeça dos maridos a respeito da legitimidade da filiação da progênie. Nestas linhas argumentativas, 
através da honra e da filiação legítima se reconhecia um homem, porquanto jamais se pode esquecer que a cidade se encontrava mergulhada na conjuntura de relações interpessoais onde se pretendia destinar ao masculino o monopólio da dominação diante das ações familiar e coletiva. O homem "apenas" suscitava consideração e se transformava em imperecível socialmente se a esposa o ajudasse a manter inquebrantável a sua honra.

Beira ao óbvio, porém, afirma-se: casar não expressava somente celebrar núpcias. Dentro destas, exigiam-se escalas de comportamentos como as acima descritas e elas constituíam-se em algumas das qualidades a se cultivar em seu bojo. Ao se darem enquanto indivíduos conjugais, outra forma de vida era implementada, desejos careciam ser partilhados e perspectivas pessoais divididas, esses aspectos caracterizam-se na faculdade de exigências incrustadas no próprio enlace, ou seja, ele se posicionava com o atributo de instituição competente para isolar [de contatos unilaterais] aqueles que certo dia decidiram pela vida a dois. O casamento partia da lógica de que duas pessoas concordaram partilhar suas vidas, ele possuía camadas de interesses, deveres e obrigações bastantes desiguais, no entanto, na sua essência tudo deveria ser comum. Casar expressava compor liames onde sua fundação concentrava-se na necessidade de suprimir relações pessoais decretando em quaisquer circunstâncias a deliberação de um compartilhamento imoderado do viver, afinal dois se uniram e formaram "única carne" ou, conforme o narrador bíblico, no Evangelho de São Mateus Capítulo 19, Versículos 5 e 6: "por isso o homem deixará pai e mãe e se unirá a sua mulher e os dois serão uma só carne? De modo que já não são dois, mas uma só carne. Portanto, o que Deus uniu, o homem não deve separar", sentença reafirmada no Evangelho de São Marcos, Capítulo 10, Versículos 7-9. (Bíblia de Jerusalém, 2002).

Os códigos da ligação legal cristã foram formatados com os afãs de controlar a sexualidade e o desejo sexual, e não de os recrudescer; assim, e novamente nos espaços da obviedade, o conúbio buscava regulamentar e dominar "instintos" tidos corruptos e o sexo em seu interior destinava-se à procriação (Vainfas, 1997; Londoño, 1999). Com leitura a contrapelo, o adultério demonstrava confessadamente o quanto as prescrições controladoras matrimoniais eram sobejamente limitativas, isso se explica porque traições, ligações teúdas e manteúdas davam-se no seio dos diversos segmentos sociais e não estiveram distantes da raridade, então, para que houvessem desenlaces conjugais, algum domínio, domínios ou quiçá tudo no laço enodoado pelo extra-lar, deu/deram errado(s), porquanto o mesmo em qualquer proposição, no absoluto, conseguiu deter o sexo fora do conúbio, ou melhor, o abrasamento em nenhum momento foi contido no seio do matrimônio ou, no mínimo, esta ação nunca esteve distante totalmente de todas as núpcias. Todavia, a respeito afirmava o articulador bíblico de Coríntios, Capítulo 7, Versículo 9: "mas, se não podem guardar a continência, casem-se, pois é melhor casar-se do que ficar abrasado" (Bíblia de Jerusalém, 2002), o problema desta sentença é quando se considera 
pertinente solucionar o abrasamento através da união e a partir desse momento, colocá-lo somente na conta dos não matrimoniados.

Tanto as fontes quanto as bibliografias, aqui interpretadas, sugerem ser propósito inviável a fusão de duas pessoas nas suas psicologias, nos seus desejos, nas suas individualidades. A vida a dois, sempre foi-é-será um jogo; ela apenas tinha-possui chances de sobrevivência se as partes derem - em qualquer tempo e espaço - margens às negociações; essa estratégia formatavase/formata-se no campo do trivial, porque antes e depois do casamento as personalidades continuavam-continuam distintas (ao contrário do aspirado pelo narrador bíblico), pois a ligadura de dois em um trata-se de articulação metafórica, nada mais.

Se, por um lado, a construção do discurso recomendava manejar bom poder de comunicação; por outro, nunca foi desprezível, no aspecto prático, entender que nenhuma linguagem consegue convencer o conjunto e concernente a isso, esta obra, está eivada de exemplos comprobatórios. A fabricação dessa rede correspondia, demasiadamente, na expressão e na extensão de condutas tidas dominantes, porém jamais apenas [é claro] a Igreja Católica e o Estado deveriam ser vigilantes e dirigentes frente a uma instituição (o casamento) considerada a base da sociedade. Vigiar o abrasamento envolvia conjunto mais múltiplo. Por possuir território infinito a organização política e administrativa do conúbio sofria, no entender de diversos maridos e esposas, fendas onde a "solução" proposta era a de impor de forma indelével limites à vida a dois, ou seja, a norma geral ou as normas gerais e suas aplicações concretas destoaram entre muitos cônjuges, ou melhor expresso, mulheres e maridos subtraíam-se dos domínios dos seus parceiros(as).

Por estes motivos, no entanto não somente por eles, tornava-se necessário dar ao consórcio ou às pessoas a ele ligado olhares vigilantes, dirigentes e dominadores compreendidos proporcionais à capacidade de forjar o abrangido por alianças sólidas e, assim, delimitar espaços correspondentes a condutas insalubres, indignas. À vizinhança, aos parentes, aos conhecidos, ou seja, às pessoas próximas e longínquas do lar conjugal "ofereciam-se" visões "menores" como se fossem "pequenos" olhos dos maridos. Havia diversas vigilâncias voltadas às esposas. Cuidava-se tanto de dar conteúdos de controle às bodas, quanto de "definir" com "nitidez" por quais meios tais conteúdos deveriam ser formatados. Dentre incalculáveis argumentos, esses engrossavam o caudal quanto a união, entretanto, em tempo algum é possível negligenciar sê-la (a união) desigual entre cônjuges em tudo e por tudo distinta.

No meio de diversas vidas em casal (eles mesmos, bem como vizinhos, amigos, conhecidos, desconhecidos, parentes) impuseram-se arrestas impossíveis de resistirem a aparas. Nos domínios da honra e da moralidade, o casamento dispunha de regulação interna própria, porque as pessoas (cônjuges, filhos, familiares) se movimentavam. No auto impetrado em 1897, 
por Antonio Ismael de Castro, 29 anos contra Adelina Rosa da Cruz Louzada, 24 anos, matrimoniados aos 18 de fevereiro de 1888 através do regime comum de bens, houve a "condenável" acusação da existência de elos extraconjugais da esposa. Na petição inicial, o autor e Temístocles de Figueiredo, seu advogado, discorreram: quando o impetrante voltou da labuta diária para o lar conjugal não mais encontrou a consorte e ao investigar, com pessoas da casa, para onde a mesma teria se dirigido tomou conhecimento de ter a mesma ido para a companhia do indivíduo Antonio Boulhosa com quem passou a conviver, à rua Monte Alegre, em adultério e escandalosa prostituição. ${ }^{5}$

Com pesada denúncia, os articuladores do auto queriam colocar o peticionário na condição de inocente frente a justiça, então, aprofundavam a situação ao observarem que o impetrante se via desobrigado a "trabalhar para quem não sabe corresponder ao seu amor", por isso, e também por outros domínios, a separação de corpos demonstrava-se elementar para o seu bem e de toda a coletividade. ${ }^{6}$ Estava em julgamento em qual lugar dever-se-ia localizar a mulher casada que consentiu experimentar outros homens e, paralelamente, definir na escala da indecência o grau dos seus "desregramentos" e "desatinos". Pesava contra à infiel ambientes negados à mulher desde à infância; nela, conforme as circunstâncias, as necessidades, as conveniências, recaíam o conceito mais cabal da irreligião, da impiedade, da libertinagem, da desumanidade diante da própria família e da sociedade. O paradigma higienista buscava organizar a cidade por meio dos referenciais da saúde e da beleza; no entanto, mesmo com as medidas propostas, as experiências sociais praticadas nas ruas de Belém e no bojo de determinados casamentos, denunciavam formas diversas de resistência $e$ fraturas nos padrões desejados. Estas relações de poder são dimensões constituidoras de tensões no bojo da cidade. Deste modo, as imagens de vida, a divergir da compreendida "normal", se devem descortiná-las no interior de linhas graduadas de manobras e de áreas de significados deixadas em aberto pelos elos dominantes em dado momento histórico.

Dominar todas as instâncias e camadas, graus e escalas sempre se apresentou inviável. Práticas prostitutas, por exemplo, na capital paraoara demonstravam-se efervescentes. Quanto a temática o "Diário de Notícias" em 30 de janeiro de 1890, narrava:

Immoralidades. Chamamos a attenção do exm. Sr. Cheffe de segurança publica, para uma prostituta, que ha 3 dias mudou-se para a travessa da Atalaya, casa $\mathrm{n}^{\circ}$ 79. Esta vibora, com a depravada linguagem que usa tem alarmado toda a visinhança, offendendo-a com immoralidades e algazarras até alta noite, de forma que os visinhos não podem dormir socegados, com as algazarras que pratica a tal víbora. Em nome da moral e dos visinhos esperamos que o exm. Sr. chefe de segurança dê providencias e estamos convicto na sua recta justiça em desaffronta dos visinhos. ${ }^{7}$ 
Ao se unir discursos, os dos jornais com os dos processos de divórcio, observou-se que eles nunca dispensaram a linguagem de a prostituição provocar irremediáveis malefícios à sociedade. Nestas trincheiras, a ruptura litigiosa do casamento celebrado sob o regime de comunhão de bens face a Igreja Católica entre Henriqueta Ferreira Penna e Costa, brasileira e José Augusto da Gama e Costa, brasileiro moradores, em 1892, a estrada de São Jerônimo, neste sentido pode corroborar. Este laço matrimonial durava, em $1^{\circ}$ de fevereiro de 1892 - dia, mês e ano da formalização do divórcio -, cerca de 22 anos. Da vida em comum surgiram "[...] Henriqueta de 19 annos de edade, Francisca de 17 annos, Rodrigo de 16 annos, Maria José de 14 annos, José de 5 annos e Pedro de 1 anno". 8 A impetrante e o seu advogado, Heraclito Vespasiano Fioch Romano, procuravam fundamentar a separação conjugal no "artigo 82 inciso $2^{\circ}$ do decreto $\mathrm{n}^{\circ}$ 181 de 24 de janeiro de 1890", isto é, sevícia ou injúria grave. ${ }^{9}$

Nos processos analisados, quando a esposa buscava sustentar o desligamento através do referido artigo e inciso, as razões a procurar culpabilizar o demandado passavam pelas moralidades conjugal e pública. Inegavelmente a honra dos maridos jamais poderia alocá-la tãosó na jurisdição das obrigações seculares atribuídas às esposas (fiéis, boas mães, dedicadas ao lar); ela também estava consignada às posturas dos próprios consortes: proteger os interesses [em toda a sua extensão] da família, conseguir provisões à linhagem, manutenção dos bens e, naturalmente, não ser dado às condutas injuriosa, sevítica e adúlteras.

Então, as arguições contidas no libelo civil de divórcio sinalizam para estas possibilidades. Por assim dizer, as motivações do desenlace giravam em torno da honra e da moralidade, ou melhor, para a ausência delas por parte do réu, porque

[...] depois de alguns annos de seo casamento, principalmente depois do fallecimento do pai da auctora, a maltrata, sevicia e a offende com injurias graves, o que é publico e notório [...] no dia 23 de dezembro do anno passado, o reo esbofeteou e espancou a auctora, injuriando-a com aprobos gravemente offensivas de sua honra e dignidade de esposa, tais como: megera, mãe desnaturada, mulher infame e outras que por decência a auctora omitte, por dignidade propria [....]. ${ }^{10}$

A fabricação dos jogos de poder tinha de passar necessariamente por articulações firmes e bem fundamentadas. Nos argumentos, há empenho à fabricação de dada versão da vida a dois ao judiciário paraense. Caminhava-se por sobre o que a legislação brasileira percebia como relações aceitáveis moralmente, neste caso específico, as proposições para se conseguir sentença favorável giravam em torno da inadequação do comportamento do esposo e da moralidade conjugal. A demandante tinha um eixo acusatório: sevícias e injúrias, as quais seriam públicas e notórias. Todavia, na segunda parte da incriminação, observaram-se conceitos desregrados do companheiro e, paralelamente, a elaboração da imagem de mulher cumpridora de tarefas 
honrosas perante a sociedade. Nos interstícios de uma ação de divórcio, quem a demandava não buscava em juízo apenas cultivar ponderações deletérias do(a) acusado(a), mas erigir boas imagens suas, era estratégia basal. No terreno movediço do auto, o(a) perpetrador(a) procurava caminhar nas intermitências morais do(a) implicado(a) e, para isso, haveria de ter gênio obstinado a colocar em xeque procedimentos (de quem se acusava) de toda ordem, ou seja, apresentar nos interstícios do judiciário que o outro (o acusado) impunha tormentos contínuos à família e aos bons costumes, os quais nunca foi capaz de prever e, por conseguinte, em virtude deles apareceram dores morais tão violentas e poderosas capazes de colocar a ordem familiar no interior das camadas mais baixas do conhecimento privado e público.

$\mathrm{O}$ (a) denunciante deveria formar de maneira inequívocas e sólidas imagens suas. Ser ou apresentar ser o(a) paladino(a) da moral, nunca foi exagerado. O perfazedor dispor de disciplina acusadora, era inalienável. Chegar os discursos, frente a justiça, "absolutamente" bem formatados entendia-se condição sine qua non à condenação. Ao sucesso da demanda, as questões a serem provadas tinham de ser bem colocadas; qualquer mal-entendido, não era permitido. Por estas trincheiras, caro leitor, haveria de se fabricar acurada trama disciplinar, onde a mesma obrigatoriamente se precipitava nas escalas enfraquecidas da família, ou melhor dito, nas fendas morais daquele indicado como o responsável do seu enfraquecimento. Nas brechas, erros e equívocos deixados pelo outro, projetava-se o poder do perpetrador. Aonde inexistia a concepção da família ideal por ter sido fraturada pelo(a) acusado(a), procurava-se fabricar um personagem o qual absolutamente em nada havia corroborado para o fim da linhagem pensada um dia, em sua unidade, inquebrantável. Retornando à matéria publicada pelo "Diário de Notícias", em 30 de janeiro de 1890, o profissional das letras jornalísticas tinha por eixo a pretensão de salvaguardar o tão decantado bem-estar moral bellepoqueano, desejo nada distante das pretensões jurídicas de Henriqueta Ferreira Penna e Costa. Esta injunção ficou inteligível quando se procurou sentir quais eram os objetivos dos movimentos das primeiras palavras impressas na segunda parte do documento: "Em nome da moral e dos visinhos [...]". Expressar e "provar" que o sujeito rompeu com paradigmas como o de boa moralidade foi referência bastante utilizada em processos de divórcio e em periódicos. Encontravam-se em jogo dimensões mais complexas: o bem-estar da sociedade, a estabilidade familiar, as normatizações pública e privada.

Em 10 de janeiro, a mesma folha publicava outra denúncia contra algumas meretrizes. Com a chamada "Calaçaria", desenvolveu:

Na casa $n^{\circ} 112$ da travessa $1^{\circ}$ de Março habitam umas meretrizes da baixa esphera sem a minima noção, já nada dizemos da moralidade publica, mas do respeito natural que cada um deve ter para com os outros. N`essa casa reunemse outras mulheres desbragadas e desconhecidas da autoridade do districto, $e$ então, repimpando-se da janella, não se lha dá de insultarem a quem quer que 
seja que passe por ali. Reunem-se também, para lhes fazer companhia, alguns pequenos vadios homens sem occupação licita, vagabundos, a quem a autoridade policial deve tomar contas severas em beneficio da sociedade. $\mathrm{Na}$ vespera e dia de REIS fizeram um banzé de todos os diabos, a ponto de ninguém poder dormir n`aquella visinhança. Esperamos providencias do sr. tenente chefe de policia. $\mathrm{N}^{\circ} 112$, travessa $1^{\circ}$ de Março. ${ }^{11}$

"Amigos da boa vida" e "fracos de formação moral", mostravam-se na qualidade de problemas sociais e assuntos de polícia, porquanto vadios ou quaisquer agentes sem ocupação passível de se admitir, eram considerados ameaçadores do coletivo e das "famílias ditas honestas". O nervosismo com aqueles menos abonados constituía-se numa das inquietações prementes em Belém, contudo, a preocupação não pode ser entendida no campo social e sim na faculdade disciplinar (Campos, 2007). O "Diário de Notícias" arrematava estabelecendo paralelo entre dois segmentos considerados "perigosos": meretrizes e "homens sem ocupação licita". Os estudos de Boris Fausto (1984, p. 33) para a São Paulo de 1880-1924 podem sobejamente auxiliar nas interpretações desses personagens sociais. Em "Crime e cotidiano" o autor descortinou, homens e mulheres desempenhadores de ocupação ilícita, na condição de indivíduos promovedores de profundos problemas à sociedade paulistana, todavia, para conter o meretrício e os homens a vagar pela cidade, as elites lançaram mão de diversas ferramentas como as prisões contravencionais e as de averiguações.

Prostituição e vadiagem localizaram-se em processos de divórcio, sendo que, não muito atrás, foram analisadas a vida fácil feminina ao passo de pesada acusação nestes tipos de auto. Eis, outra problemática do gênero. "Aos 02 de setembro, Ano do Nascimento de Nosso Senhor Jesus Cristo de 1900, capital do Estado do Pará”, Raymundo Santos Viveiros, operário e Carlita Dantas Gonçalves, prendas domésticas, impetrante e impetrada, respectivamente, iniciaram oficialmente separação contenciosa. O laço matrimonial ocorrera em 18 de dezembro de 1888, dois filhos surgiram do agora exausto elo, os quais ao tempo da desunião eram impúberes de 09 e 11 anos, os seus nomes não constam no libelo. Entretanto, os rebentos estavam sob a guarda do demandante e da mãe deste, onde conjuntamente ofereciam proteção e educação "devendo continuar do mesmo modo". ${ }^{12}$ Santos Viveiros e seu advogado, José Augusto Meira Dantas, acusavam formalmente a esposa daquele de práticas licenciosas as quais por decência privada e pública a desunião conjugal se tornava inadiável. Na petição inicial, colocavam em pauta de julgamento: "após o nascimento do $2^{\circ}$ e ultimo filho, a sua mulher seduzida pelo individuo João Bernardo de Oliveira, deixou o lar e adulterando entregou-se a uma vida toda irregular. Deixando por sua vez, o reducto, como ficou esteve algum tempo, amasiou-se com um bombeiro municipal e ainda depois foi para Manaos". ${ }^{13} \mathrm{O}$ adultério neste casamento, era altamente reprovável. Classificado na instância de imoralidade com potencial de colocar fim imediato na vida a dois, 
seja o adultério considerado "passatempo", seja o que veio a constituir outra família, rompia valores compreendidos na classe do legítimo. Miasma do conúbio, ele conseguia adoecer os sangues ligados solenemente, reverter sentimentos, colocar na condição de adversárias pessoas unidas (pelo menos nas perspectivas teóricas) eternamente. Aderido ao adultério, se encontravam profundos medos, por exemplo, o de a progênie ser contaminada pelo germe da ilegitimidade, pelos vícios públicos e de levar ao leito familiar doenças como a sífilis. Dispersava o querido na escala de inseparável; a sua presença na família indispunha de "qualquer" possibilidade de aquela sobreviver, assim aquando da denúncia e ao tempo da sua "comprovação", o adultério possuía força contumaz atroz para enodoar vidas e manchar honras. A este respeito, em texto nada recente, Alain Corbin $(1992$, p. 112, 119) reconheceu à França do século XIX que para um jovem burguês solteiro, mas também ao homem matrimoniado, seus "sonhos" era o de "possuir a mulher do outro"; mas perfilha o autor existir uniões ilegítimas em todos os segmentos sociais, entre pequenos e médios burgueses e em meio dos mais "desfavorecidos".

Segundo o "Diário de Notícias" de 10 de janeiro de 1890 (matéria atrás impressa) a vagabundagem feriria a honra e as moralidades privada e pública. A respeito o "Código Penal da República dos Estados Unidos do Brasil de 1890", no artigo 399, capítulo XIII, livro III, dizia: "Deixar de exercitar proffissão, officio, ou qualquer mister em que ganhe a vida, não possuindo meio de subsistencia e domicilio certo em que habite; prover a subsistencia por meio de occupação prohibida por lei, ou manifestamente offensiva da moral e dos bons costumes". ${ }^{14} \mathrm{O}$ infrator deste artigo do Código Penal seria condenado à prisão celular de 15 a 30 dias. Porém, se ocorresse reincidência, o artigo 400 afirmava: "Si o termo for quebrado, o que importará reincidencia, o infractor será recolhido, por um a tres annos, a colonias penaes que se fundarem em ilhas marítimas, ou nas fronteiras do territorio nacional, podendo para esse fim ser aproveitados os presidios militares existentes". ${ }^{15} \mathrm{O}$ inciso $1^{\circ}$ do artigo 399 complementava: "Pela mesma sentença que condemnar o infractor como vadio, ou vagabundo, será elle obrigado a assignar termo de tomar occupação dentro de 15 dias, contados do cumprimento da pena". ${ }^{16}$ Conjugando as duas documentações - a publicização do periódico com os artigos do Código Penal - vê-se o quanto o regime republicano se preocupava com o significado do trabalho. É preciso lembrar: responsabilizava-se o homem pelo sustento da família. O Decreto-Lei 181 de 24 de janeiro de 1890, artigo 56 inciso $5^{\circ}$, estabelecia como efeitos do casamento: "Obriga o marido a sustentar e defender a mulher e os filhos". ${ }^{17}$ Exigia-se dele a prática de atividades profissionais percebidas pelas leis e sociedade no eixo do legal. Punições contra aqueles distantes de qualquer ofício, tornavam-se necessárias; as leis traziam em suas linhas a exaltação "dos bons costumes" e em conformidade com isso, é conveniente acentuar que os sujeitos sem trabalho se constituíam, na 
cidade de Belém, numa inconveniência social e quando aparecia esta acusação nos processos de divórcio tudo tendia a ficar muito austero ao impetrado.

Dar-se a um afazer era basal. Nunca foi casual as testemunhas e os impetrantes de autos serem caracterizados como dados à labuta. Tornava-se imprescindível estabelecer elos entre os sujeitos em juízo com a ética do trabalho, à honra e à moralidade, pois estes estavam articulados e sempre estiveram classificados na qualidade de elementos ordenadores da coletividade. Desta maneira, a constituição de bons trabalhadores em nenhum momento poderia ficar aquém destas pretensões, uma vez que o homem habituado ao labor era a base da civilização, dos bons costumes e do progresso. Por assim dizer, ser comprometido com alguma ocupação tornava-se fundamental. De tal modo, as testemunhas dos libelos de divórcio não se encontravam excluídas, ao contrário, para seus depoimentos conter alguma legitimidade jurídica imprescindia-se desse valor.

\section{Profissões das testemunhas}

\begin{tabular}{|c|c|c|c|}
\hline Homens & & Mulheres & \\
\hline Agente de polícia & 01 & Doceira & 01 \\
\hline Artista & 04 & Parteira & 01 \\
\hline Caldeireiro & 01 & Serviços domésticos & 03 \\
\hline Carpina & 01 & & \\
\hline Carpinteiro & 02 & & \\
\hline Comerciante empregado no comércio & 03 & & \\
\hline Empregado no comércio & 05 & & \\
\hline Empregado no curro & 01 & & \\
\hline Empregado no Hospital da Ordem Terceira & 01 & & \\
\hline Empregado público & 03 & & \\
\hline Funileiro & 01 & & \\
\hline Guarda livros & 02 & & \\
\hline Livreiro & 01 & & \\
\hline Marítimo & 02 & & \\
\hline Militar & 01 & & \\
\hline Negociante & 01 & & \\
\hline Padre & 01 & & \\
\hline Pescador & 01 & & \\
\hline Prático & 01 & & \\
\hline Proprietário & 01 & & \\
\hline Serralheiro & 01 & & \\
\hline Talhador & 01 & & \\
\hline Trabalhador & & \\
\hline & & \\
\hline & & \\
\hline & & \\
\hline & & \\
\hline & & \\
\hline & & \\
\hline & & \\
\hline
\end{tabular}

Quadro elaborado pelo autor a partir da análise de 21 processos (litigiosos e amigáveis) catalogados no Arquivo Geral do Tribunal de Justiça do Estado do Pará 
Walter Fraga Filho (1996) buscou compreender as bases da ética do trabalho na Bahia do século XIX; para tal intento, concentrou esforços no papel repressor das autoridades policiais contra a vadiagem estabelecida na cidade, isto é, os limites da indigência e da itinerância aproximavam-se de comportamentos marginalizados. A exigência de se ter um ofício, tornava-se necessária às testemunhas para que seus depoimentos tivessem o mínimo de verossimilhança na justiça, tais táticas sobejamente estiveram presentes nas imputações fabricadas nos entreveros jurídicos litigiosos impetrados pelos belenenses. As temáticas atrás expostas - trabalho, prostituição, família, moralidade - foram corriqueiramente utilizadas para se sustentar desuniões de corpos e bens. Nesta conjuntura, acusação de prostituição lançada pelo réu à demandante, em 22 de setembro de 1894, tem-se nas tramas de Ernestina Pereira de Sousa, 30 anos, brasileira, profissão não declarada e Lourenço Justiniano de Sousa, 41 anos, brasileiro, empregado público. Os cônjuges, à época, moravam na casa número 18 da estrada de Nazaré. A razão legal a sustentar a ruptura firmou-se no artigo 82 inciso $2^{\circ}$ do Decreto 181 de 24 de janeiro de 1890: sevícia ou injúria grave. A demandante asseverou possuir "[...] motivos poderosos para se divorciar de seu marido [...]" ${ }^{18}$ A mulher se queixava inexistir, por parte do esposo, o necessário "respeito conjugal, maltratando-a por palavras e obras" e a este conjunto somavam-se sevícias e injúrias infligidas sucessivamente e acompanhadas de escândalo público, sendo que no dia 19 de maio de 1894, o justificado ameaçou matá-la. ${ }^{19} \mathrm{~A}$ autora constituiu duas testemunhas, as quais confirmaram, no Tribunal de Justiça do Estado do Pará, a versão dos fatos apresentada no libelo do processo. José Estevão da Rocha Filho, jurou sob os Santos Evangelhos dizer apenas a verdade, contava, no ano de 1894, 21 anos, solteiro e trabalhava como prático. Sobre as incriminações iniciais, narrou diligentemente o cotidiano conjugal da seguinte forma:

[...] que por diversas vezes vio o justificado mal tratar a justificante, sua mulher, por palavras e obras, isto é, proferindo contra ella umas injurias e chegando mesmo a bater-lhe [...] que vio o justificado bater em sua mulher uma vez, mas que isto foi feito publicamente, de modo tal que pessoas que passavam na rua chegaram mesmo a parar para presenciar o facto que dava-se no interior da casa de moradia de ambos os cônjuges [...] que quanto ao facto visto no dia 19 de Maio do corrente anno, tem a declarar o seguinte caso a testemunha occular: que estando a conversar na sala da casa onde residia o justificado e a justificante na referida noite de 19 de Maio, vio aquelle, o justificado, á proposito de uma conversa que a justificante entretinha com uma mulher que a encomendara de fazer um vestido, levantou-se e investiu contra a sua mulher, a justificante em quem batteu com as mãos e perseguio até a casa de uma vizinha para onde a justificante refugiara; e ali chegando o justificado ameaçou-a em sua existência com uma navalha que lhe foi arrancada das mãos pela testemunha e por um irmão do próprio justificado, acrescentou mais, a testemunha que esse facto se deu com escandalo publico, pois a justificante refugiou-se á casa da vizinha, 
fugindo á perseguição de seu marido, teve necessidade de atravessar a rua o que chamou a attenção da vizinhança e de pessoas que na occasião por ali passavam $[\ldots] .^{20}$

Se as pessoas envolvidas nestes entreveros compreendiam importantes balizar os percursos das suas próprias Histórias, eis um ano a ser lembrado: 1894. A união consagrada vinha exausta e desacordos em meio aos casados ou ao menos as imputações ditas ocorridas, apresentavam as coisas em escalas profundamente delicadas e nesta esteira é importante pensar alguns significados da moral no bojo do casamento, por assim dizer compreende-se que "todos" sabem da inviabilidade prática de a núpcia se encerrar no compartilhamento imoderado de duas vidas, ou seja, de duas pessoas transformadas em uma e ausente de perquirições, no entanto o "intolerável" como sevícias e injúrias, ao aparecer, prudentemente se lançava mão e transformá-las em eficazes armas nos corredores do judiciário era tarefa elementar aos advogados, impetrantes, testemunhas. Ir ao judiciário delatar agressões (quer dos homens, quer das mulheres) provenientes de dado lugar (do casamento), o qual deveria ser ou se mostrar ser a base da sociedade, acabava por fazer dele uma espécie de caução ao indivíduo acusador, porque se rompiam estruturas da honra, da moralidade, dos bons costumes. No cotidiano da vida a dois, agredir dispunha de leis próprias de gradação e, por isso, as pessoas inseridas nestes entreveros (aqui se referem aos cônjuges, aos filhos, aos parentes, aos vizinhos, aos conhecidos) não raramente classificavam o ataque em camadas, o tolerável e o intolerável, por um lado; por outro, essa compreensão apresentava-se capilar ao judiciário, ou seja, no seio da referida lógica, os domínios poderiam piorar "exatamente" na mesma proporção se tudo fosse orquestrado diante da opinião pública. Expressando-se em condições mais claras: transeuntes participando de entreveros conjugais; parando para observar com olhares sempre agudos e atentos os passos da vida alheia; verificando ocorrências de porta adentro do lar dos cônjuges; desinteligências seguidas por perseguições das vítimas pelas vias públicas; invasão do agressor da casa de vizinhos, porque estava a caça do seu alvo, o judiciário alocava estes fatos na escala do agravo sobejo. Quando em depoimento a testemunha dizia ter presenciado violências, ameaças de morte, participação de transeuntes e da vizinhança nos entreveros, o judiciário fazia isso pesar contra o acusado, mesmo nunca significando a certeza de condenação.

Reforçava-se a versão apresentada. O cotidiano conjugal estava permeado de sobressaltos e problemas (sevícias e injúrias graves), inclusive com promessas de assassinato. Esta denúncia era portadora de representações acusatórias bastante expressivas no interior do Tribunal de Justiça, pois colocava o réu em situação jurídica delicada, uma vez que se publicizava a relação conjugal ser composta de alardes, os quais nada se resolviam no âmbito do privado da vida conjugal e sim por meio de escândalos públicos, os quais feriam a honra e a moral. $\mathrm{O}$ afã era o de 
a honra e a moral se ligar eternamente como se fossem irmãs siamesas, porém elas somente poderiam se fazer a partir da constituição da ética, ou seja, esta deveria estar naquilo que explicarealiza e nunca no alinhamento, tão-somente, do prescrito ou do recomendado.

A narrativa de Rachel Maria de Rosario, 40 anos, solteira, analfabeta, doceira, moradora da casa número 14 da estrada de Nazaré, em nada destoou do prestado por José Esteves da Rocha Filho; as estratégias foram bem estabelecidas pelos interessados na separação de corpos e bens. Quanto aos movimentos sociais do impetrado, dona Raquel observou:

[...] que estando jantando em sua casa na noite do dia 19 de Maio do corrente anno foi despertada por um barulho que partia do corredor para lá se dirigindo, verificou que Lourenço Justiniano de Sousa, o justificado, agarrou entre as mãos a sua mulher Ernestina Pereira de Sousa que protestava pôs amarras de ir embora e que neste interim apareceu um irmão do justificado que o levou para a casa, e que voltando algum tempo depois mostrou á dona Ernestina uma navalha que, disse, ter Lourenço Justiniano de Sousa se armado d'ella para ferila, digo, para cortá-la. ${ }^{21}$

Os depoimentos se uniam, convergiam. Todavia, estas imputações seriam refutadas pelo impetrado por meio da forma mais clássica: acusando a esposa de adúltera, logo de ter manchado a sua honra, dignidade e moralidade de homem sempre afeito às obrigações familiares. Maridos bastante se apropriaram da principal conjugação acusatória (para eles): a existência de elos extraconjugais das mulheres, onde aliavam esta séria má conduta à denúncia formal. De modo imaginário ou não, o adultério rondava as cabeças de certos esposos do final do século XIX, nesta conjuntura, a qual armava-se com diligência ou não, o medo de ter sido traído era premente. No entanto, aqui, o fato a se ocupar é que a intimidade entre mulher e voos extramatrimoniais jamais poderiam ser descortinados apenas no grau de um fato a ocorrer com o corpo da estranha, da vizinha, da amiga da família, da esposa do outro, a infidelidade rondava a própria esposa. $\mathrm{O}$ adultério é classificado para além de uma ofensa ao companheiro constituído, ele injuriava a família, afrontava a sociedade, era uma contradição entre o censurável e o permitido. Os preceitos conjugais são verdadeiras fusões de exigências, onde - naturalmente - escalas amorosas extras não faziam parte delas. Ao se realizar um cotejamento entre as leis da época (Decreto 181 de 24 de janeiro de 1890 e os Códigos Penal e Criminal), jurisconsultos como Lafayette Rodrigues Pereira (1889) com a obra "Direito de família", Rui Barbosa (1951) com "O divórcio" e Clovis Bevilaqua (1896) no seminal "Direito da família" e argumentos contidos em autos de divórcio, expuseram o adultério no eixo da corrupção máxima da vida a dois. Esposas e maridos ao lançarem mão desta prática desleal e insalubre, faziam secundarizar o ato sexual higiênico idealizado e, então, difundiam atrozes consequências à família constituída. 
Utilizando-se dos discursos da existência de despudoramento e de aventuras extraconjugais da esposa, Lourenço Justiniano de Sousa procurava refutar as faltas recaídas sobre si: a de seviciador e a de agente de escândalos públicos. Ao contestar o libelo deu da forma seguinte a sua versão, leia-se o excerto:

[...] a Autora tem faltado ao respeito e á fé conjugais, por palavras e por obras; que a Autora, longe de corresponder ao carinho e ao disvello com que a tratava o reo, trahiu-o, ferindo-o em sua honra; que a Autora adulterou; que a Autora com tal procedimento incorreu na sanç̧ão penal do art. 279 do Código respectivo; que a Autora se acha na expressa disposição do $\S 1^{\circ}$ do art. 82 do dec. 181 de 24 de janeiro de 1890, incursa; que a Autora abandonou o domicilio conjugal, voluntariamente, por tel-a o Reo chamado ao cumprimento de seus deveres matrimoniais $[\ldots] .{ }^{22}$

Quando réu, procurar projetar na esposa a condição de adúltera foi estratagema recorrente. $\mathrm{O}$ impetrado acusava-a de ter dilatado as amarras conjugais, assim, a denunciava no artigo 279 do Código Penal, que alocava o adultério feminino como passivo de prisão ${ }^{23}$ e, igualmente, no inciso $1^{\circ}$ (adultério) do artigo 82 do Decreto 181 de 24 de janeiro de $1890 .{ }^{24} \mathrm{O}$ extraconjugal feminino possuía diversas dimensões no interior do direito, isto é, aventuras fora dos laços matrimoniais eram classificadas na teia da prostituição por romperem referenciais supostamente ancorados na honra e na moralidade, por assim dizer, a inviolabilidade dos lares passava necessariamente por um irrepreensível comportamento das mulheres. A imputação de adultério impingida pelo esposo à mulher era portadora de peso expressivo, pois o mais leve dos deslizes femininos poderia ser visto na condição de práticas ilegítimas. Ao tempo da união consagrada não seguir a geografia a ela atribuída como a mais elementar de todas, a da fidelidade, isso muitos aspectos poderiam representar: o "rigor" da Igreja, da legislação, das posturas das partes envolvidas (cônjuges, famílias de ambos os lados, vizinhança, grupo social), indispunham de ferramentas globais de controle, porquanto há, nas alianças, tanto concernente ao seu interior quanto nos seus arrabaldes, evolução sentimental; assim sendo, quando as núpcias são vistas na qualidade de prisão, na circunstância de jaula onde se encontram "sem movimento" dois animais (os cônjuges) a perecerem pausadamente, muitas vezes o adultério e o desenlace foram as soluções encontradas à fatigada vida a dois. A corrupção da infidelidade facilmente conduzia na sua esteira inumeráveis custos agregados: a decomposição da lealdade, a corrosão da dignidade, mais enfraquecimento da vida em comum, a separação dos consortes e a dos pais-filhos, a divisão de bens (sempre muito tensa), a mutação da honra, expressavam alguns dos seus pivôs. Até onde este historiador foi capaz de chegar, adulterar carregava conjunto de características interrelacionadas onde se torna improvável alguém conseguir expor [na totalidade] suas consequências, porém crê-se prudente colocá-lo na condição de uma hidra de cabeças várias. 
As articulações contidas nos periódicos e as projeções acusatórias existentes nos processos de divórcio litigiosos, muito são próximas. Nesta dimensão, o adultério-prostituição não se constituía em um mal necessário, ao contrário, ele se apresentava como face do despudoramento. Recorre-se aqui a obra de Luzia Margareth Rago, "Os prazeres da noite" (1991). A prostituição foi analisada por meio de duas dimensões: instituto desregrador dos movimentos morais, mas também na variável da imagem de mal necessário, porque era preciso preservar a virgindade para futuras bodas. Aqui, analisou-se a prostituição sob outros ângulos, ela nos processos de divórcio belenenses esteve conectada às práticas de adultério e jamais foi aceita habitualmente quer pelos cônjuges, quer pelos juízes, quer pelas testemunhas, quer pela família, quer pela Igreja, quer pelas leis.

Com efeito, houve na cidade de Belém da última década oitocentista múltiplos planos de possibilidade quando o assunto perpassava pela honra e moralidade.

\section{Considerações finais}

No decorrer do tempo e espaço deste estudo a honra e a moralidade, indivíduos e instituições, procuravam ligá-los ao casamento, contudo, a sua prática, em alguns enlaces, nem sempre foi como maridos e esposas idealizaram. Em Belém entre 1894 e 1900, mulheres e homens casados, conforme necessidades e condutas do outro consorte, decidiram colocar em xeque esta instituição que ajudava a manter a celebração matrimonial no patamar de inquebrantável, então, este estudo deixou evidente o quanto a fragmentação da honra conduziu diversos entreveros ao laço conjugal e, consequentemente, diversas disputas nos corredores do Tribunal de Justiça do Estado do Pará em forma de processo de divórcio.

A manutenção da honra no seio do casamento passava por conjunto de valores, os quais apenas os casados tinham o poder de consolidá-la e fragmentá-la. No bojo do conúbio, para que o homem mantivesse a cabeça erguida havia a dependência das "boas condutas" da esposa, isto é, a companheira nunca ser dada ao adultério constituía-se em condição sine qua non à continuidade dela. No entanto, honra não era apenas sinônimo de bons comportamentos femininos para com os maridos; a esposa e a coletividade, igualmente, exigiam condutas adequadas dos esposos no sentido de preservá-la quer para si, quer para a mulher. A honra também esteve ligada à provisão, à segurança da companheira, a da linhagem, à habitação, ou seja, a dimensões político-econômicas de competência dos maridos, segundo as leis republicadas do final do século XIX.25

No interior do casamento, qualquer significado oferecido à honra passava obrigatoriamente por comportamentos ditos inculcados ao estado de matrimoniado. Por esta 
escala interpretativa, a conservação da honra, bem como a sua fragmentação sucessivamente esteve aderida aos movimentos de dignidade práticos pelos consortes, logo, não se tratava de efeitos externos da vida a dois e sim de acertos e desacertos executados conjugalmente. Por assim dizer, tal instituto tão valoroso e caro ao casamento foi caracterizado, neste estudo, enquanto sistema de valor essencial à vida conjugal, porém que nunca dependeu, no seio do casamento, de único personagem. Isto posto, normas e posturas (umas pesando mais e outras menos sobre os ombros dos que se ofereceram em compromisso para a vida eterna) estavam dadas no cerne da relação a dois e o papel dos envolvidos era o de cumprir as exigências expostas.

Mas, para muitos casais, a linha a separar norma e corrupção foi muitas vezes transposta e, desta maneira, a continuidade da vida sob o mesmo teto era alocada em condições inexecutáveis. Se, por um ângulo, a honra buscava murar a vida conjugal; por outro, quando ocorria a sua fragmentação, territórios eram perdidos, tudo degringolava e se descolonizava, ou melhor, a honra era instituto tênue posto que ela tinha o poder de nutrir, ordenar e determinar condutas entre marido e mulher, contudo, quando enodoada dispunha de força para assentar duas almas em campos de batalha absolutamente opostos.

Finalmente, o marido de posse da fidelidade da esposa era o mais nobre dos homens, mas quando corrompida detinha a prerrogativa de deixá-lo na mais baixa escala das relações sociais. Para as esposas, o rebaixamento da honra acontecia quando seus companheiros estabeleciam condutas adúlteras, negligenciavam no campo da provisão e proteção da linhagem, por exemplo. Por estas perspectivas, a honra no seio do casamento sempre foi objeto de tensões.

\section{Documentos}

Divórcio litigioso promovido por Placida de Andrade e Silva contra Ildefonso João da Silva, 1900.

Divórcio litigioso promovido por Raymundo Santos Viveiros contra Carlita Dantas Gonçalves, 1900

Divórcio litigioso promovido por Antonio Ismael de Castro contra Adelina Rosa da Cruz Louzada, 1897.

Divórcio litigioso promovido por Ernestina Pereira de Sousa contra Lourenço Justiniano de Sousa, 1894.

Decreto no 181 de 24 de janeiro de 1890. In: Decretos do Governo Provisório da República dos Estados Unidos do Brasil de 1890. Primeiro fascículo de 1 a 31 de janeiro de 1890. Rio de Janeiro: Typ. da Imprensa Nacional, 1890.

Diário de Notícias. Belém, 02 de janeiro de 1890, pp. 03 e 04.

Diário de Notícias. Belém, 10 de janeiro de 1890, p. 03. 
Diário de Notícias. Belém, 30 de janeiro de 1890, p. 03.

“Capítulo IV: Do adultério ou infidelidade conjugal, art. 279”. In: Código Penal da República dos Estados Unidos do Brasil de 1890. Rio de Janeiro: Typ. da Imprensa Nacional, 1890.

"Livro III: Das contravenções em espécie, Capítulo XIII: Dos vadios e capoeiras, art. 399, § 10". In: Código Penal da República dos Estados Unidos do Brasil de 1890. Rio de Janeiro: Typ. da Imprensa Nacional, 1890.

“Livro III: Das contravenções em espécie, Capítulo XIII: Dos vadios e capoeiras, artigos 399 e 400”. In: Código Penal da República dos Estados Unidos do Brasil de 1890. Rio de Janeiro: Typ. da Imprensa Nacional, 1890.

\section{Referências}

BARBOSA, Rui. O divórcio. Rio de Janeiro: Edição da Organização Simões, 1951.

BEVILAQUA, Clovis. Direito da família. Recife: Ramiro M. Costa Editores, 1896.

Bíblia de Jerusalém. São Paulo: Paulus, 2002.

CAMPOS, Ipojucan Dias. Repressão, higiene e disciplina na Belle-Époque belenense (1890-1900). Revista Textos e Debates (UFRR), n 13, 2007, p. 103-129.

CORBIN, Alain. (org.). A obrigação da virilidade, fonte de ansiedade e angústia. In: História da virilidade. O triunfo da virilidade: o século XIX. Vol. II. Rio de Janeiro: Vozes, 2013, p. 439-461.

CORBIN, Alain. A fascinação do adultério. In: Amor e sexualidade no Ocidente. Porto Alegre: L \& PM, 1992, p. 112-119.

ENGEL, Magali. Meretrizes e doutores: saber médico e prostituição no Rio de Janeiro (1840-1890). São Paulo: Brasiliense, 1989.

FAUSTO, Boris. Crime e cotidiano: a criminalidade em São Paulo (1880-1924). São Paulo: Brasiliense, 1984.

FRAGA FILHO, Walter. Mendigos, moleques e vadios na Bahia do século XIX. São Paulo: HICITEC, 1996.

LONDOÑO, Fernando Torres. A outra família: concubinato, Igreja e escândalo na Colônia. São Paulo: Loyola, 1999.

PEREIRA, Lafayette Rodrigues. Direito de familia. Rio de Janeiro: Typ. da Tribuna Liberal, 1889.

PERROT, Michelle (org.). Dramas e conflitos familiares. In: História da vida privada: da Revolução Francesa à Primeira Guerra. Vol. IV. São Paulo: Companhia das Letras, 2001, p. 263-285.

PHILLIPS, Roderick. Desfazer o nó: breve história do divórcio. Lisboa: Terramar, 1991.

PORCHAT, leda. (org.). Amor, casamento, separação: a falência de um mito. São Paulo: Brasiliense, 1992.

RAGO, Luzia Margareth. Imagens da prostituição na Belle-Époque paulista. De trajetórias e sentimentos. Cadernos Pagu, $n^{\circ}$ 1, 1993, p. 31-44. 
RAGO, Luzia Margareth. Os prazeres da noite: prostituição e código da sexualidade feminina em São Paulo 1890-1930. Rio de Janeiro: Paz e Terra, 1991.

SAMARA, Eni de Mesquita. Mistérios da "fragilidade humana": o adultério feminino no Brasil, séculos XVIII e XIX. Representações. Revista Brasileira de História-ANPUH, n 29. São Paulo: Contexto, 1995, p. 57-71.

VAINFAS, Ronaldo. Trópico dos pecados: moral, sexualidade e inquisição no Brasil. Rio de Janeiro: Nova Fronteira, 1997.

${ }^{1}$ Divórcio litigioso promovido por Placida de Andrade e Silva contra Ildefonso João da Silva, 1900.
2 Divórcio litigioso promovido por Placida de Andrade e Silva contra Ildefonso João da Silva, 1900.
${ }^{3}$ Divórcio litigioso promovido por Placida de Andrade e Silva contra Ildefonso João da Silva, 1900.
${ }^{4}$ Diário de Notícias. Belém, 30 de janeiro de 1890, p. 03.
${ }^{5}$ Divórcio litigioso promovido por Antonio Ismael de Castro contra Adelina Rosa da Cruz Louzada, 1897.

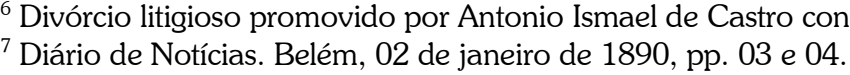

${ }^{8}$ Segundo item do libelo civil de divórcio. Divórcio litigioso promovido por dona Henriqueta Ferreira Penna e Costa contra José Augusto da Gama e Costa, 1892.

${ }_{9}^{9}$ Artigo e inciso em que se procurou sustentar o divórcio litigioso promovido por dona Henriqueta Ferreira Penna e Costa contra José Augusto da Gama e Costa, 1892.

${ }^{10}$ Partes do libelo civil de divórcio impetrado por dona Henriqueta Ferreira Penna e Costa contra José Augusto da Gama e Costa, 1892.

${ }^{11}$ Diário de Notícias. Belém, 10 de janeiro de 1890, p. 03.

${ }^{12}$ Divórcio litigioso promovido por Raymundo Santos Viveiros contra Carlita Dantas Gonçalves, 1900.

${ }^{13}$ Divórcio litigioso promovido por Raymundo Santos Viveiros contra Carlita Dantas Gonçalves, 1900.

14 "Livro III: Das contravenções em espécie, Capítulo XIII: Dos vadios e capoeiras, art. 399, § 10". In: Código Penal da República dos Estados Unidos do Brasil de 1890. Rio de Janeiro: Typ. da Imprensa Nacional, 1890.

15 "Livro III: Das contravenções em espécie, Capítulo XIII: Dos vadios e capoeiras, artigos 399 e 400". In: Código Penal da República dos Estados Unidos do Brasil de 1890. Rio de Janeiro: Typ. da Imprensa Nacional, 1890.

16 "Livro III: Das contravenções em espécie, Capítulo XIII: Dos vadios e capoeiras, art. 399, § 1'”. In: Código Penal da República dos Estados Unidos do Brasil de 1890. Rio de Janeiro: Typ. da Imprensa Nacional, 1890.

${ }^{17}$ Decreto 181 de 24 de janeiro de 1890, "Capítulo VII: Dos efeitos do casamento, art. 56, § 50". In: Decretos do Governo Provisório da República dos Estados Unidos do Brasil de 1890. Primeiro fascículo de 1 a 31 de janeiro de 1890. Rio de Janeiro: Typ. da Imprensa Nacional, 1890.

${ }^{18}$ Divórcio litigioso promovido por Ernestina Pereira de Sousa contra Lourenço Justiniano de Sousa, 1894.

${ }^{19}$ Divórcio litigioso promovido por Ernestina Pereira de Sousa contra Lourenço Justiniano de Sousa, 1894.

${ }^{20}$ Parte do depoimento prestado por José Estevão da Rocha Filho em favor da impetrante Ernestina Pereira de Sousa, 1894.

${ }^{21}$ Parte do depoimento prestado por Rachel Maria do Rosario em favor da impetrante Ernestina Pereira de Sousa, 1894.

${ }^{22}$ Parte da contestação do libelo de divórcio impetrado por Ernestina Pereira de Sousa contra Lourenço Justiniano de Sousa, 1894.

23 “Capítulo IV: Do adultério ou infidelidade conjugal, art. 279”. In: Código Penal da República dos Estados Unidos do Brasil de 1890. Rio de Janeiro: Typ. da Imprensa Nacional, 1890.

${ }^{24}$ Decreto n 181 de 24 de janeiro de 1890. In: Decretos do Governo Provisório da República dos Estados Unidos do Brasil de 1890. Primeiro fascículo de 1 a 31 de janeiro de 1890. Rio de Janeiro: Typ. da Imprensa Nacional, 1890.

${ }^{25}$ Decreto no 181 de 24 de janeiro de 1890. In: Decretos do Governo Provisório da República dos Estados Unidos do Brasil de 1890. Primeiro fascículo de 1 a 31 de janeiro de 1890. Rio de Janeiro: Typ. da Imprensa Nacional, 1890. 